\title{
Regional approach to labour costs management as factor of increasing competitive ability and effectiveness of crop growing production
}

\author{
Raisa Sergeevna Shepitko \\ Volgograd state university \\ Economics and finances institution \\ Economic theory, global and regional economics \\ department \\ Volgograd, Russia \\ rss1302@yandex.ru
}

\author{
Tatiana Aleksandrovna Dugina \\ Volgograd state agricultural university \\ Economics department \\ Department of economic security and economics in \\ agricultural business industry \\ Volgograd, Russia \\ deisi79@mail.ru
}

\author{
Aleksander Vladimirovich Nemchenko \\ Volgograd state agricultural university \\ Economics department \\ Department of economic security and economics in agricultural business industry \\ Volgograd, Russia \\ volgsnemchenko@mail.ru
}

\begin{abstract}
It is impossible to increase competitive ability and effectiveness of agricultural industry without scientific grounds to develop indicators of resource intensity as one of the tools to achieve the target goals. The article explains the approaches of developing of enlarged normative of labor costs in agriculture, recommended as the key points for selecting the technological model of modernization and basis to define needs of labor resources on the example of certain agricultural region of Russia, that is the Volgograd region.

In their research work the authors rely on labor content per unit of output for 5 natural zones and 33 municipal units, typical and pilot businesses in these zones, as well as on calculated values of labor intensity for agricultural crops growing. For processing the total data there is used factor and structural analyses, correlative and regression models, statistical methods of uniformity of aggregate data evaluation, that were the basis for developing structural model for forming the labor cost in croups growing. Its components defined the scenario approach to develop labor intensity and expert method of evaluation within the great variety allowed to find background initial basis for their development.

Enlarged norms of labor costs in crop growing development is based on the theory to use integrated index, considering all factors of competitive ability and effectiveness (natural technological, organizational and economical). Within the suggested hypothesis there are introduced ideas such as 'structural' hectare and labor cost for the 'structural' hectare, as well as their content and methods of calculation are explained.

Calculations, made according to the suggested methods were tested in 27 business units of the region and calculated values of the indicators proved to be reliable and accurate. Considering the existing types of agricultural industry production in the region there was detected the area of their implementation, their practical value for effective management.
\end{abstract}

Keywords - region, region's natural zone, competitive ability, effectiveness, factors, scenario, approach, expert opinion, indicators, labor intensity, structural hectare, technological model

\section{INTRODUCTION}

Agriculture industry is a complex production and economic system. Providing with information plays important role in its functioning. Transition to programming and goal making management and indicative planning made this problem actual as for finding ground and developing of indicators of expensed for making of agricultural industry products. We need to know this branch, otherwise it is impossible to manage reasonably, plan strategically, provide with innovative scenario of agriculture industry development. That will make native agriculture industry competitive among other countries with developed agriculture industries.

Effectiveness of modernization processes criteria is workforce productivity and factors of its growth are usage of high-producing machines, progressive technologies, social and economic partnership within the labor relations and other. On the basis of this approach to organize agricultural production, certain manufacturers can compete with leading manufactures of agriculture products as of technological labor intensity for agricultural crops growing [1]. This is the basis to develop labor intensity for agricultural crops growing in Russian regions indicators as the reference point for location of agricultural industry and selecting of methods to increase its competitive ability and effectiveness. [2,3]. 


\section{MATERIALS AND METHODS (MODEL)}

Labor intensity is one of the leading indexes of labor use in agriculture industry effectiveness, represented as labor intensity as per product unit; 1 ha of agricultural crops growing; 1 head of livestock. Crop production, the same as for industry [4] has got technological labor intensity (direct expenses of labor per produced product unit, 1 ha), management labor intensity (manages labor costs per one unit of product, $1 \mathrm{ha}$ ), service labor intensity (labor costs of main personal, providing services for the main process per unit of product, 1 ha) and total (aggregate) labor intensity as sum of all types of labor intensity.

Labor intensity per one hectare of agricultural crops from one side reflects the direct labor costs per one technological stage of agriculture products production, and from the other, along with yielding capacity is the factor directly influencing on labor intensity of the product. [5]. This quality of index 'labor intensity per one ha' describes the cause-and-effect relationship factors, covering technology, machines park and natural conditions. [6,7].

Technology of agricultural crops growing should be considered depending on soil and climate conditions, Volgograd region has got 5 natural zones [8,9]. The most favorable for agricultural crops growing is the $1^{\text {st }}$ steppe zone of chernozem soils, where soil score is 1.8 times higher its value in the $4^{\text {th }}$ zone, and amount of precipitations is 2 times higher than in semi desert zone of light chestnut soil. That was the reason of crops growing intensity as of natural zones, defined by formed system of agriculture industry and the respective technology and used machines [10,11].

The highest specific values of labor intensity as of two main crops of the region (cereals and sunflower) are indicated in the $1^{\text {st }}$ zone (TABLE I).

TABLE I. LABOR INTENSITY FOR PRODUCTION OF MAIN TYPES OF AGRICULTURAL CROPS ACCORDING TO NATURAL ZONES OF THE VOLGOGRAD REGION

\begin{tabular}{|l|c|c|c|c|c|c|c|}
\hline No & Natural zone & \multicolumn{3}{|c|}{ Cereals } & \multicolumn{2}{c|}{ Sunflower seeds } \\
\cline { 2 - 7 } & $\begin{array}{c}\text { Direct labor } \\
\text { costs per I } \\
\text { ha, man } \\
\text { hour/ha }\end{array}$ & $\begin{array}{c}\text { Yielding } \\
\text { capacity, } \\
\text { c/ha }\end{array}$ & $\begin{array}{c}\text { Labor } \\
\text { intensity of } \\
\text { the product, } \\
\text { man hour/c }\end{array}$ & $\begin{array}{c}\text { Direct labor } \\
\text { costs per I I } \\
\text { ha, man } \\
\text { hour/ha }\end{array}$ & $\begin{array}{c}\text { Yielding } \\
\text { capacity, } \\
\text { c/ha }\end{array}$ & $\begin{array}{c}\text { Labor } \\
\text { intensity } \\
\text { of the } \\
\text { product, } \\
\text { man } \\
\text { hour/c }\end{array}$ \\
\hline I & $\begin{array}{c}\text { Steppe zone of } \\
\text { chernozem } \\
\text { soils }\end{array}$ & 10.4 & 20.9 & 0.50 & 11.4 & 13.2 & 0.86 \\
\hline II & $\begin{array}{c}\text { Dry steppe } \\
\text { zone of dark } \\
\text { chestnut soils }\end{array}$ & 7.7 & 12.8 & 0.60 & 6.0 & 6.9 & 0.87 \\
\hline III & $\begin{array}{c}\text { Dry steppe } \\
\text { zone of light } \\
\text { chestnut soils }\end{array}$ & 8.3 & 13.0 & 0.64 & 6.7 & 6.9 & 0.97 \\
\hline IV & $\begin{array}{c}\text { Left bank zone } \\
\text { of chestnut } \\
\text { soils }\end{array}$ & 8.6 & 12.0 & 0.72 & - & - & - \\
\hline V & $\begin{array}{c}\text { Semi desert } \\
\text { zone of light } \\
\text { chestnut soils }\end{array}$ & 4.2 & 5.0 & 0.84 & - & - & - \\
\hline
\end{tabular}

These values showed that this technological model provided the highest yielding capacity and relatively low labor intensity of products. Decreasing of labor costs per one ha from the $1^{\text {st }}$ to the $5^{\text {th }}$ zone is equal to yield decrease of agriculture crops and decreasing of labor capacity. This is due to use of simple technologies of cropping because of low return of additional investments in the zones with less favorable soil and climate conditions. We used mathematic functions such as linear, quadratic, exponential to prove the connection between the level of intensity and labor intensity, all they proved that natural factor and intensification influence much on technological labor intensity of products. Regression coefficient for all types of equalizing for the cereals is from 0.75 to 0.78 , and for sunflower from 0.76 to 0.82 .

Structural analyses of unit costs as for crops showed, that labor intensity is not the same. The most labor intensity is for vegetables (948.05 man-hour/ha), then potato (226.17 manhour/ha), then cucurbits crop (15.31 man-hour/ha). If their share in seeding increase the labor cost in crop production also rapidly increase. For example, labor intensity of growing of 1 ha of vegetables is in 4-5 times higher, than at growing of cereals and sunflower, that is why if these crops are present at the crop rotation would be important factor to consider number of personnel and their salary budget.

There is observed great variability of labor costs at homogeneous cropping, not only for natural zones (TABLE II), but inside the zones as well, for municipal units.

TABLE II. VARIETY OF UNIT LABOR COSTS FOR CROPPING FOR THE NATURAL ZONES OF VOLGOGRAD REGION, MAN POWER/HA

\begin{tabular}{|l|c|c|c|c|c|}
\hline \multirow{2}{*}{ Crop } & \multicolumn{5}{c|}{ Natural zone } \\
\cline { 2 - 6 } & $\boldsymbol{I}$ & II & III & IV & $\boldsymbol{V}$ \\
\hline Cereals & 9.9 & 3.5 & 10.0 & 4.4 & 2.6 \\
\hline Sunflower & 19.3 & 4.3 & 16.8 & 2.7 & - \\
\hline Corn for seeds & 15.3 & 5.1 & - & - & - \\
\hline Soja bean & 19.9 & - & - & - & - \\
\hline Feed crop & 12.1 & 5.9 & 7.1 & 9.3 & 12.3 \\
\hline Cucurbits crop & - & - & - & 8.3 & - \\
\hline
\end{tabular}

In the steppe zone of chernozem soils minimal expenses of cereals cropping are 6 man-hour, maximal is 15.9 , which makes the range 9.9. As for sunflower seeds it is 6.6; 25.9 and 19.3 accordingly. This state of variety is for all crops within the zone.

Natural conditions for agricultural industry functioning influenced on ratio of crops. There is certain structural of crops in every natural zone. There are mostly cereals and sunflower. In all areas the share of these two crops is from 66.3 to $88 \%$.

From I to V zone increases value of feed crops. This is proved for farmer's sector where there is livestock farming. For example, at farms of left bank zone the feed crops are about $11 \%$, at the semi desert zone of light chestnut soils $22 \%$. At the Gorodischensky district (III zone) the second important crop after the cereal $(42.8 \%)$ is vegetables $(22.9 \%)$, and in Bykovsky district (IV zone) it is cucurbits crop (19.2\%). This distinguishes their structure from the average for the zone.

At the Palasovsky district ( $\mathrm{V}$ area) feed crops are represented as $30 \%$, comparing with average for the zone for 
this municipal unit, the share of the feed crops is only $12 \%$. Moreover, even for the same crop within one zone there is great variety for different municipal units. For example, at the steppe zone of chernozem soils with the average share of cereals $57.2 \%$, the variety is from $44.8 \%$ to $86.4 \%$ for the agricultural industry and from $41.8 \%$ to $71.6 \%$ at farms, as for sunflower - from $13.6 \%$ to $38.8 \%$ and from $17.2 \%$ to $41.8 \%$. Deviations from average values are from 1.5 to 2 times for all zones. Therefore, the structural of crops along with labor intensity of agricultural crops is important factor in grounding of labor costs for production of agricultural products and need in work force as for the natural areas and municipal units, as well as for the goods producers.

That is why we consider it to be reasonable to introduce the idea of 'structural' hectare $\left(\mathrm{C}_{\text {га }}\right)$ and labor intensity of 'structural' hectare $\left(\mathrm{TC}_{\mathrm{ra}}\right)$.

Structural hectare is the structural (share) of crop acreage per 1 ha. It is calculated as:

$$
\mathbf{c}_{\mathrm{ra}}=\sum_{i=1}^{n} 4 i
$$

with $\mathrm{C}_{\mathrm{ra}}$ - for structural hectare;

$Д_{i}-$ share of respective crop per 1 ha of seeding.

For this purpose we need to define cropping for the 'structural hectare' for every zone and municipal unit. Those are the crops, which have 2 or more percent in the structural of crop acreage.

Labor intensity for cultivating of 'structural' hectare is defined as sum of productions of crops share $\left(\Sigma Д_{i}\right)$ and individual indicator of direct expenses of a certain crop $\left(\mathrm{UT}_{\mathrm{i}}\right)$ according to the equation:

$$
\mathrm{TC}_{\mathrm{ra}}=\Sigma Д_{i} \mathrm{KT}_{i}
$$

with $\mathrm{TC}_{\mathrm{ra}}$ - is the labor intensity of the 'structural' hectare;

ИТ $_{\mathrm{i}}$ - for indicator of direct expenses for cultivating of 1 ha of a certain agricultural crop.

To make calculated values of the 'structural' hectare objective and accurate the individual indicator of labor intensity for cultivating of one 1 ha $\left(\mathrm{UT}_{\mathrm{i}}\right)$ is defined by method of expert evaluations within scenario approach to selection of technological models. At evaluation of aggregate likeness there were used statistical methods of analyses, based on variation coefficient [12].

\section{RESULTS AND DISCUSSION}

Evaluation of labor intensity for cultivating of one hectare of homogeneous crops for the natural zones and within one zone (TABLE II) showed wide range of variations, not allowing using average values of labor costs as basic for developing of norms for labor intensity for cropping.

For elimination of wide range of variations in each zone there is detected of group of typical businesses. Their data, along with average data are used as reference for grounding of basic indicator of labor intensity for each crop, together with information of the pilot businesses, located at areas of certain crop cultivation. Pilot businesses are defined by expert method on the basis of such criteria, as level of technologisation of industry, gained yielding capacity, publicity and accuracy of labor costs calculation. We should also consider calculated values as certain pilot businesses show very low labor content per unit of output.

The calculation is done within technological models, used in agricultural businesses that are considered to be pilot. Basic level is yielding capacity for this technological model and type of facilities, machines park and output standard. In general, there were examined 52 technological models, for each of them there was defined labor intensity of 1 ha cultivating. Thus individual indicator of 1 ha labor intensity for the crops $\left(\mathrm{UT}_{\mathrm{i}}\right)$ can be defined on the basis of:

- Actual average data of labor cost for the zone;

- Actual average data of labor cost of typical businesses of the zone;

- Actual average data of labor cost of pilot businesses of the zone;

- Calculated labor costs.

On the basis of actual and calculated data of direct labor costs for cropping we can tell that:

- There is difference between actual and calculated specific indicators of labor costs per 1 ha of agricultural crops due to not only technologies of cultivation, but also errors during calculation;

- Cropping at the region is done by traditional and also by progressive technologies of the 'no-till' and 'mini-till' type. They significantly decrease labor costs for cropping, that is proved by pilot businesses data. For example, at the agricultural holding ZAO Geluo-Paks units of the Volgograd region direct labor costs for cropping are in 2 or more times lower than for other member of agricultural market, operating at the same natural conditions;

- Machines park for technological operations is defined by technological model for production of agricultural goods. It is not identical and effects labor intensity of cropping. At steppe zone of chernozem soils there are classified traditional, progressive and combined technological types of production at the agriculture industry. Natural conditions of this zone provide high effectiveness of resource saving technologies for economical as well as for ecological criteria. Unfortunately, at other zones these technologies are not so advantageous.

All information, indicated above becomes the basis data of labor costs for cultivation of 1 ha of agricultural crops to accept calculated data considering their updating as on the following conditions:

- Possible errors of technological process modelling, there is possible lack of technological operations (10-15\%);

- Uncertainty of process in agriculture industry (precipitations, dry hot wind, dry weather, illnesses, depredators). That is why there is need in additional technological operations (15-20\%);

- Scenario approach to calculation of labor intensity for cropping on the basis of technological models for the natural zones;

- Cereals at the calculations are represented by winter wheat, the mostly spread in the region, traditionally for system of dryland agriculture located on fallow lands;

- Labor intensity of other crops is accepted on the level of labor intensity for the cereals. 
Considering the mentioned above conditions increased the costs of labor per unit for cropping for $32.3 \%$ (TABLE III).

TABLE III. CALCULATED INDICATORS OF LABOR INTENSITY FOR CROPPING IN MAN-HOURS/ HA

\begin{tabular}{|c|c|c|c|}
\hline \multirow[t]{2}{*}{ Crop } & \multicolumn{3}{|c|}{ Technology } \\
\hline & Progressive & Traditional & Composed \\
\hline \multicolumn{4}{|c|}{ Steppe zone of chernozem soils } \\
\hline Winter wheat & 1.27 & 3.14 & 2.95 \\
\hline Summer wheat & 1.45 & 1.98 & 1.62 \\
\hline Sunflower & 1.89 & 2.11 & 1.92 \\
\hline Corn for wheat & 1.84 & 3.14 & 2.50 \\
\hline Soybeans & - & 3.83 & - \\
\hline Other oil-bearing crop & - & 4.63 & - \\
\hline Feed crop & - & 2.77 & - \\
\hline \multicolumn{4}{|c|}{ Dry steppe zone of dark chestnut soils } \\
\hline Winter wheat on fallow land & \multicolumn{3}{|c|}{5.49} \\
\hline Summer wheat & \multicolumn{3}{|c|}{3.79} \\
\hline Sunflower & \multicolumn{3}{|c|}{7.67} \\
\hline Other oil-bearing crop & \multicolumn{3}{|c|}{4.63} \\
\hline Cucurbits crop & \multicolumn{3}{|c|}{15.31} \\
\hline Feed crop & \multicolumn{3}{|c|}{5.91} \\
\hline \multicolumn{4}{|c|}{ Dry steppe zone of light chestnut soils } \\
\hline Winter wheat on fallow land & \multicolumn{3}{|c|}{4.57} \\
\hline Sunflower & \multicolumn{3}{|c|}{3.87} \\
\hline Soybeans & \multicolumn{3}{|c|}{3.52} \\
\hline Vegetables & \multicolumn{3}{|c|}{948.05} \\
\hline Potato & \multicolumn{3}{|c|}{226.17} \\
\hline Feed crop & \multicolumn{3}{|c|}{5.91} \\
\hline Cucurbits crop & \multicolumn{3}{|c|}{15.31} \\
\hline \multicolumn{4}{|c|}{ Left bank zone of chestnut soils } \\
\hline Winter wheat on fallow land & \multicolumn{3}{|c|}{4.1} \\
\hline Corn for seeds & \multicolumn{3}{|c|}{9.12} \\
\hline Potato & \multicolumn{3}{|c|}{226.17} \\
\hline Vegetables & \multicolumn{3}{|c|}{948.05} \\
\hline Cucurbits crop & \multicolumn{3}{|c|}{15.31} \\
\hline Feed crop & \multicolumn{3}{|c|}{5.91} \\
\hline \multicolumn{4}{|c|}{ Semi desert zone of light chestnut soils } \\
\hline Winter wheat on fallow land & \multicolumn{3}{|c|}{6.77} \\
\hline Feed crop & \multicolumn{3}{|c|}{5.91} \\
\hline Summer wheat & \multicolumn{3}{|c|}{5.26} \\
\hline Vegetables & & 948.05 & \\
\hline
\end{tabular}

The updated data were taken as indicators of labor intensity for cropping for the natural zones $\left(\mathrm{UT}_{\mathrm{i}}\right)$ during calculation of labor intensity of 'structural' hectare. Their level is not exclusive of other investigations in this field $[13,14]$.

On the basis of formed structural of crop acreage and calculated labor intensity of agricultural crops the authors calculated labor intensity of 'structural' hectare for the municipal units and categories of businesses (TABLE IV).
TABLE IV. LABOR INTENSITY OF 'STRUCTURAL' HECTARE IN AGRICULTURAL BUSINESSES OF VOLGOGRAD REGION, MAN-HOUR/HA

\begin{tabular}{|c|c|c|c|}
\hline \multirow{2}{*}{ Zone, district } & \multicolumn{3}{|c|}{$\begin{array}{l}\text { Labor intensity of 'structural' hectare } \\
\text { man hour }\end{array}$} \\
\hline & Progressive & Traditional & Composed \\
\hline Steppe zone of chernozem soils & 1.53 & 2.77 & 2.55 \\
\hline Alekseevsky & 1.58 & 2.81 & 2.57 \\
\hline Danilovsky & 1.35 & 3.00 & 2.81 \\
\hline Elansky & 1.49 & 2.68 & 2.45 \\
\hline Kikvidzensky & 1.60 & 2.71 & 2.42 \\
\hline Kumylzhensky & 1.43 & 2.86 & 2.64 \\
\hline Mikhailovsky & 1.53 & 2.73 & 2.51 \\
\hline Nekhaevsky & 1.68 & 2.86 & 2.59 \\
\hline Novoanninsky & 1.53 & 2.73 & 2.50 \\
\hline Novonykolaevsky & 1.58 & 2.68 & 2.44 \\
\hline Urupinsky & 1.56 & 2.61 & 2.36 \\
\hline $\begin{array}{l}\text { Dry steppe zone of dark } \\
\text { chestnut soils }\end{array}$ & \multicolumn{3}{|c|}{5.78} \\
\hline Zhirnovsky & \multicolumn{3}{|c|}{6.30} \\
\hline Kletsky & \multicolumn{3}{|c|}{5.41} \\
\hline Kotovsky & \multicolumn{3}{|c|}{5.87} \\
\hline Olkhovsky & \multicolumn{3}{|c|}{5.58} \\
\hline Serafimovichsky & \multicolumn{3}{|c|}{5.85} \\
\hline Frolovsky & \multicolumn{3}{|c|}{5.65} \\
\hline $\begin{array}{l}\text { Dry steppe zone of light } \\
\text { chestnut soils }\end{array}$ & \multicolumn{3}{|c|}{30.49} \\
\hline Dubovsky & \multicolumn{3}{|c|}{4.62} \\
\hline Gorodischensky & \multicolumn{3}{|c|}{232.80} \\
\hline Ilovlinsky & \multicolumn{3}{|c|}{4.75} \\
\hline Kalachevsky & \multicolumn{3}{|c|}{6.54} \\
\hline Kamyshinsky & \multicolumn{3}{|c|}{4.73} \\
\hline Kotelnikovsky & \multicolumn{3}{|c|}{14.27} \\
\hline Oktyabrsky & \multicolumn{3}{|c|}{4.69} \\
\hline Surovikinsky & \multicolumn{3}{|c|}{4.68} \\
\hline Chernyshkovsky & \multicolumn{3}{|c|}{4.58} \\
\hline $\begin{array}{l}\text { Left bank zone of dry steppe } \\
\text { zone of chestnut soils }\end{array}$ & \multicolumn{3}{|c|}{6.13} \\
\hline Bykovsky & \multicolumn{3}{|c|}{9.15} \\
\hline Nikolaevsky & \multicolumn{3}{|c|}{4.54} \\
\hline Staropoltavsky & \multicolumn{3}{|c|}{4.26} \\
\hline $\begin{array}{l}\text { Semi desert zone of light } \\
\text { chestnut soils }\end{array}$ & \\
\hline Svetloyarsky & \multicolumn{3}{|c|}{18.85} \\
\hline Sredneakhtubinsky & \multicolumn{3}{|c|}{68.74} \\
\hline Leninsky & \multicolumn{3}{|c|}{22.86} \\
\hline Palasovsky & \multicolumn{3}{|c|}{6.51} \\
\hline
\end{tabular}

Considering the fact that labor intensity of 'structural' hectare is defined by ratio of crops and indicator of direct expenses of the certain crop it is different not only for the natural zones and municipal units inside the zone but also for manufactures of different forms of businesses. It is explained by different structures of crop acreage.

\section{CONCLUSION}

The suggested method for calculation of labor cost was implemented for the conditions of 27 businesses of Volgograd region, all pf them are located in different natural zones. As the analyses detected, calculation of direct labor costs at crops growing industry on the basis of 'structural' hectare is true and reliable for businesses of the I, II, III zones where cereals, industrial and feed crops are grown. In such businesses the difference of labor costs calculated according to the 'structural' hectare and on the basis of individual labor intensity of every crop is minimal or absent. This is true for each of the five zones. That is why the suggested method of calculation of enlarged norms of labor intensity in crops growing industry on the basis of 'structural' hectare should be recommended for businesses of the similar production type.

For businesses in which within the structure of crop acreage along with cereals, industrial and feed crops there are 
such labor consuming crops as vegetables, cucurbits crops, potato, general labor costs can be reasonably defined on the basis of developed individual labor intensity and area of crop. That can be explained by the fact that businesses of the fourth and fifth zones, comparing with the first three have different production specification: growing of cereals, cereals and industrial crops, cereals and cattle rearing business, growing of vegetables and potato and cucurbits crops. Each production type is connected with cropping has different labor intensity and the calculated enlarged norms on the basis of 'structural' hectare would not be accurate.

The developed individual indicators of cropping labor intensity and indicator of labor intensity of the 'structural' hectare can be used as following:

- They can be tools for detecting of reserves of competitive ability increasing and effectiveness of cropping products;

- They can be normative basis for project solutions, defining needs in workforce and salary fund act crops growing industry;

- They can be reference point at selecting of technical and technological options;

- They can be criteria for bringing the governmental grants to the receivers;

- They can be elements of indicative planning in agricultural business of the region.

\section{References}

[1] Gollin, Douglas, Lagakos, David, Waugh, Michael E. Agricultural productivity differences across countries. // Am. Econ. Rev. - 2014. - № 104 (5). - P. 165-170.

[2] Malik M.Y., Nuzhna O.A. Competitive ability of agricultural companies: methods and techniques: monography.-K.: Institution of agricultural economics, 2007. -270 pp.
[3] Ignatova T.V., Vasilyev P.P. Pecularities for forming of labor potential as factor for economic modernization. - Rostov-on-Don: Everast, 2014 $-164 \mathrm{pp}$.

[4] Sergeev I.V. Economics of a company. - M.: Finances and statistics, 2003. - p.226.

[5] Kizhlay G.M., Kochurova E.V., Rogaleva N.S. Effectiveness use of labor resourses as factor of productivity of agricultural goods growth // Agrarny vestnik of Ural. - No 06 (148). - 2016. - pp. 101-110.

[6] Külekçi M. Technical efficiency analysis for oilseed sunflower farms: a case study in Erzurum, Turkey. // Journal of the Science of Food and Agriculture. - 2010. - № 90, - P. 1508-1512

[7] Katore, J.R., Ingole, P.G., Paslawar, A.N., Kubde, K.J., Sajid, M. (2015), Studies on sunflower production and efficiency as influenced by preceding legumes, crop residue management and nitrogen levels to sunflower // Ecology, Environment and Conservation Paper. - 2015. - № 21. - P. 353-357.

[8] Shepitko R.S., Dugina T.A., Nemchenk A.V. Modernization of economic relations within the sphere of government support of agriculture industry // International agrictulture journal. - No2. - 2017. pp. 39-41.

[9] Winters Paul, Timothy Essam, Benjamin Davis, Alberto Zezza, Calogero Carletto, Kostas Stamoulis. Patterns of rural development: a cross-country comparison using microeconomic data // ESA Working Paper - No. 08-06 August - 2008. -36 p.

[10] Petrova I. Use of fertilizers - important branch for intensification of cereals productopn // Agricultural industry of Russia. - 2014. - No 5. pp. 45-51.

[11] Shepitko R.S., Korabelnikov I.S. Background and potential of innovative development of agriculture industry. - city of Volgograd, Volgograd agricultural university, 2017. - $151 \mathrm{pp}$.

[12] Eliseeve I.I., Yuzbasheva M.M. General theory of statistics. - M.: Finanses and statistics, 2015. - 272 pp.

[13] Reference book of agricultural industry economist / edited by A.A. Chernyaev, city of Saratov, 2012. - 339 pp.

[14] Reference book of agricultural industry economist edited by T.M. Vasylyeva, V.V. Makavetsky, M.M. Maksimov. - M.: Colos, 2010. $528 \mathrm{pp}$. 